\title{
STUDENTS' PERCEPTIONS OF SERVICE QUALITY, SATISFACTION, AND WORD- OF-MOUTH: SCALE ADAPTATION AND VALIDATION ON A SAMPLE OF ICT AND STEM STUDENTS
}

\section{PERCEPCIJE STUDENATA O KVALITETI USLUGE, ZADOVOLJSTVU I USMENOJ PREDAJI - PRILAGODBA I EVALUACIJA MJERNE LJESTVICE NA UZORKU ICT I STEM STUDENATA}

\author{
Market-Tržište \\ Vol. 30, No. 2, 2018, pp. 195-211 \\ UDK 378.18:378:004 \\ DOl http://dx.doi.org/10.22598/mt/2018.30.2.195 \\ Preliminary communication
}

\section{Dunja Meštrovića, Nina J. Zugic ${ }^{b}$}

a) University of Rijeka, Ulica Radmile Matejčić 2, 51000 Rijeka, CROATIA, e-mail: dmestrovic@uniri.hr

b) British Council Consultant, 32 Broomhouse Road, London SW6 3QX, UNITED KINGDOM, e-mail: ninazugich@gmail.com

\begin{abstract}
Purpose - The purpose of this empirical research is to adapt and adopt a measurement tool that will accurately assess students' perceptions of higher education (HE) service quality (SQ), as well as the students' overall satisfaction (SS) and their word-of-mouth (WoM) behavior. The target groups are information communication technology (ICT) and science, technology, engineering, and mathematics (STEM) students.
\end{abstract}

Design/Methodology/Approach - The paper introduces the process of adaptation, adoption, and psychometric validation of the proposed ICT \& STEM SQ-SSWoM measurement scale, consisting of the following sections: students' demography, perceptions of SQ, and WoM intentions survey. After the initial administration of tests, followed by the pilot testing and scale purification, quantitative data were collected from 214 ICT and STEM students. Statistical tests were applied in two stages, involving an analysis of the scale's validity, followed by that of its reliability and dimensionality.

\section{Sažetak}

Svrha - Svrha ovog empirijskog istraživanja jest prilagoditi i ponuditi mjernu ljestvicu koja će precizno procijeniti percipiranu kvalitetu usluge visokog obrazovanja, ukupno zadovoljstvo studenata i prenošenje informacija usmenom predajom. Ciljne su skupine studenati informacijskih i komunikacijskih tehnologija (ICT) i studenti koji studiraju u područjima znanosti, tehnologije, inženjerstva i matematike (STEM).

Metodološki pristup - $U$ radu se opisuje proces prilagodbe, usvajanja i psihometrijske provjere predložene ICT \& STEM SQ-SS-WoM mjerne ljestvice, koja se sastoji od četiri dijela: demografskih podataka studenata, izjava o percepcijama kvalitete usluge, zadovoljstva studijem i namjerama usmene predaje. Nakon provedenog pilot-istraživanja i modificiranja upitnika, empirijski podaci prikupljeni su od 214 ICT i STEM studenata. Odgovori ispitanika podvrgnuti su statističkim testovima u dvije faze, a kako bi se potvrdila valjanost, pouzdanost i dimenzionalnost mjerne ljestvice. 
Findings and implications - The confirmatory factor analysis yielded 24 SQ items, categorised under 5 factors, 4 SS items, and 3 items measuring students' positive WoM intentions, which confirmed all the scale's psychometric characteristics except its discriminant validity.

Limitations - Besides the unconfirmed discriminant validity, this student-focused study used a sample of 4 public ICT and STEM HE settings in Croatia and was confined to the students' perspective; thus, the results obtained should be interpreted within its limitations.

Originality - The results of this research suggest an acceptable model fit, thus proposing the usability of the adapted measurement scale and contributing to the extant literature reporting findings on SQ, SS, and positive WoM intentions within the ICT and STEM HE context.

Keywords - higher education, perceived service quality, scale development, students' satisfaction, word of mouth
Rezultati i implikacije - Primjenom konfirmatorne faktorske analize dolazi se do zaključka da predloženi mjerni instrument, koji se sastoji od 24 čestice vezane za percepcije o kvaliteti usluge razvrstane u 5 faktora, 4 čestice za mjerenje zadovoljstva studijem i 3 čestice za mjerenje namjera usmene predaje studenata, osim diskriminativne valjanosti, ima i zadovoljavajuće metrijske osobine.

Ograničenja - Nedostatak uspostave diskriminativne valjanosti, uz usmjerenost na studente i uzorak ispitanika sa 4 ICT i STEM sastavnice javnog sveučilišta u Hrvatskoj, može se smatrati glavnim ograničenjima ovoga istraživanja koje obuhvaća isključivo percepcije studenata. Stoga je rezultate potrebno tumačiti unutar navedenog konteksta.

Doprinos - Rezultati istraživanja upućuju na zaključak da predložena mjerna ljestvica, osim diskriminativne valjanosti, ima i zadovoljavajuće psihometrijske osobine. Stoga ovaj rad predstavlja doprinos postojećoj literaturi iznošenjem rezultata istraživanja o percipiranoj kvaliteti usluge, zadovoljstva studijem i namjerama usmene predaje studenata u ICT i STEM visokoobrazovnom kontekstu.

Ključne riječi - visoko obrazovanje, percipirana kvaliteta usluge, razvoj mjerne ljestvice, zadovoljstvo studenata, usmena predaja 


\section{INTRODUCTION}

Information and communication technology (ICT), together with the science, technology, engineering, and mathematics (STEM) higher education (HE) are considered to be major generators of innovation, positive changes, and development in a knowledge-based society (Joyce, 2014). Thus, the availability and delivery of such knowledge and education is considered an imperative for government bodies and HE stakeholders. Therefore, they should focus on educational access and the quality of its provision to students, who, as direct consumers of HE services, are the most important beneficiaries.

According to Lewis (1989), service quality (SQ) is a pivotal source of competitiveness and a compelling success requirement in the services sector. In addition, according to Berry, Parasuraman and Zeithaml (1988), SQ is the most effective tool for the majority of organizations in the services sector. Accordingly, DeShields, Kara and Kaynak (2005) affirmed the idea of improvement of students' retention by the advancement of SQ.

Moreover, Johns, Avci and Karatepe (2004) suggest that a high level of SQ consequently leads to the improvement of consumer satisfaction, while SQ and consumer satisfaction represent an antecedent of customer loyalty (Cronin, Brady \& Hult, 2000; Imrie, Durden \& Cadogan, 2000; Cristobal, Flavian \& Guinaliu, 2007). Loyal customers are likely to spread positive wordof-mouth (WoM) communication (Reichheld \& Dado, 1990; Athiyaman, 1997), which is considered by Reichheld (2003) to be the only relevant indicator necessary for companies to grade and evaluate the loyalty of their customers.

Consequently, the premise that SQ enhancement results in an increase of both customer satisfaction and loyalty should highlight their importance as constituents in a wider marketing context of sustainability of the ICT and STEM HE industry, and of the society as a whole. A review of the literature affirmed no single extensive and easily accessible SQ and Students' Satisfaction (SS) questionnaire for either ICT and/or
STEM students; Very limited evidence has also been provided in it to demonstrate the process of development and assessment of psychometric properties of an instrument assessing ICT and STEM students' perceptions of HE SQ, SS, and students' positive WoM intentions. Thus, the main purpose of this paper was to adapt and adopt a scale measuring ICT and STEM students' perceptions of SQ, SS, and positive WoM intentions (ICT \& STEM SQ-SS-WoM), and to explore its validity and its reliability.

This empirical research was part of a larger study undertaken within a project approved by the University of Rijeka and administered among the students in the university's STEM and ICT programs, project number 2015/46: "Students' satisfaction and attitudes towards service quality and efficiency in study."

\section{LITERATURE REVIEW}

\subsection{Service quality}

Service quality (SQ) has been among the most extensive marketing research topics over the last few decades (Gallifa \& Batalle, 2010). Segoro (2013) suggested that SQ implies consumers' perceptions about the quality and quantity of the benefits received by their purchase and consumption of certain products or services. On the whole, researchers do agree that SQ has a positive impact on satisfaction (Parasuraman, Zeithaml \& Berry, 1988; Cronin et al., 2000). In addition, SQ represents an essence of establishing and sustaining a favorable relationship with customers (Meštrović, 2017) and should therefore be considered as an antecedent to satisfaction (Bigne, Moliner \& Sanchez, 2003). Cronin and others (2000) found satisfaction to be a significant mediator of the relationship between SQ and behavioral intentions, thus providing support for the suggestion that SQ is an antecedent to satisfaction.

Arslanagić-Kalajdžić, Kadić-Maglajlić and Čičić (2014) describe HE services as highly characterized by intangibility, heterogeneity, perishability, 
and lack of ownership, in addition to inseparability of customers' presence, service delivery, and service consumption. Within the HE context, each stakeholder (e.g. students, their parents, university employees, government, and professional bodies) has a distinct point of view of SQ that depends on their specific interests and needs. This empirical research focuses on one particular stakeholder group within $\mathrm{HE}$, namely, students. In the context of the nature and the scope of this research, SQ was defined as "students' subjective perception and evaluation of the performance level of the services provided by the HEl [higher education institution], compared with their expectations" (Meštrović, 2017: 68).

Due to increasing competition in the HE market, HEls became aware of the importance of their performance, including what caused the emergence of the acceptance of market-based concepts and taking into account the values of SQ perceptions, satisfaction, WoM, etc. (Arslanagić-Kalajdžić et al., 2014). In addition, Ahmed and others (2010) argued that HE SQ should be considered as a key performance indicator to measure educational excellence, and that it should be used as the main strategic tool to create desired and strong perceptions in consumers' minds.

\subsection{Student satisfaction}

Student satisfaction is variously perceived and, consequently, variously defined in the services and consumer marketing literature. Kotler and Clarke (1987), for example, defined satisfaction as an individual attitude and as the perception of the difference between expectations and perceived service consumption. Oliver (1981: 29), on the other hand, defined satisfaction as "the summary psychological state resulting when the emotion surrounding disconfirmed expectations is coupled with the consumer's prior feelings about the consumption experience."

Student satisfaction has been widely extended to all service areas, including HE. It is of fundamental interest to HEls, which aim to consistently enhance the learning environment for stu- dents and attain the requirements of the widest possible range of stakeholders. In the HE context, student satisfaction was defined by Udo, Bagchi and Kirs (2011) as an overall evaluation of students' learning experience, while Sapri, Kaka and Finch (2009) explain that it can be predicted by three aspects, namely, by service delivery, performance of trainers, and support facilities. Student satisfaction can be also defined as a student's subjective appraisal of his or her educational experience.

Some researchers (Elliott \& Healy, 2001; Vázquez, Aza \& Lanero, 2015) have focused on students as customers and assessed student satisfaction in HE following the methodology previously used in general customer satisfaction measurements. The results of their studies confirmed the positive impact of student satisfaction on student motivation and retention, HEls' recruiting efforts, and fundraising, thus emphasizing the importance of SS (Elliott \& Shin, 2002).

In addition, according to Elliott and Shin (2002), student satisfaction also occurs when perceived service performance either achieves or transcends students' inconstant expectations. Richardson (2005), for example, used diverse dimensions to determine students' perceptions of learning environment quality in relation to student satisfaction. Alves and Raposo (2010) explained that students' positive perceptions of $\mathrm{SQ}$, observed from the aspect of academic as well as administrative efficiency of an $\mathrm{HEl}$, have a significant impact on student satisfaction and that satisfied students attract prospective students through their positive WoM communication. Consequently, based on the findings mentioned above, HEls should consider SQ the key performance parameter that leads to better understanding of student satisfaction, and also fosters students' positive WoM communication.

\subsection{Word of mouth}

Anderson (1998: 6) defined word of mouth (WoM) as an "informal communication between private parties concerning evaluations of goods and services." WoM is a phenomenon 
that occurs when a consumer is either satisfied or dissatisfied with a product or a service they have consumed (Davidow \& Leigh, 1998). There is no general consent among researchers about how WoM should be approached and thus measured. However, the measurement of the WoM construct appears to be rather challenging. Godes and Mayzlin (2004) focused specifically on information being spread in their research, examining WoM volume and dispersion. In addition, Fullerton and Taylor (2002) studied why loyal customers do not all provide positive WoM, while Wirtz and Chew (2002) and File, Cermak and Prince (1994) concentrated on WoM as consumers' sharing about their experiences.

With a focus on HE, Webb and Jagun (1997) proposed a definition for the concept of loyalty as students' intention to recommend an HEl, their willingness to share positive experiences about it, and their tentative intention to enrol at the same HEl in order to continue their studies. On the contrary, Athiyaman (1997) described students' loyalty as the aggregation of students' intentions of positive discourse about their university and their willingness to encourage prospective students by providing them with positive information.

As a result, a subsequent study acknowledged positive WoM as informal, person-to-person communication about perceived HE SQ, developed between non-commercial senders and receivers (Harrison-Walker, 2001), which seems to be increasingly popular and has a greater influence on consumers' choice than traditional, commercial forms of communication (Murray, 1991). Bristor (1990) and Murray and Schlacter (1990), on the other hand, argued that WoM's influence is greater in the context of services than in that of products, but that it differs from one service sector to another. Subsequently, Bansal and Voyer (2000) agreed and further explored the existence of higher risk in some service purchase situations than in others, while Mazzarol and Soutar (2002) highlighted the educational context as a specific service sector, in which WoM seemed to be particularly important.

\section{METHODOLOGY}

The conceptual framework shown in Figure 1 arose from the concepts from the literature review and from a series of formal and informal discussions that were intended to broadly illustrate the proposed concept. The posited measurement instrument was multidimensional, so the recommendations for scale development procedures proposed by Gerbing and Anderson (1988) and DeVellis (2003) were considered and described as follows.

\section{FIGURE 1: Proposed research model}

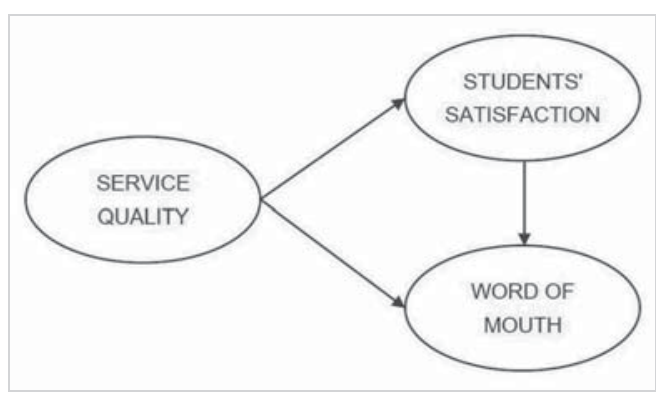

Source: Authors

\subsection{ICT \& STEM SQ-SS-WoM scale - adaptation and adoption}

The ICT and STEM students' perceptions of SQ, SS, and positive WoM intentions (ICT \& STEM SQSS-WoM) scale used in this study was originally adopted from previous research and adapted to measure the ICT and STEM students' perceptions of SQ, their satisfaction, and their positive WoM intentions (Meštrović, 2017). The development process of the ICT \& STEM SQ-SS-WOM scale began with item adoption and modification. Additionally, new items were introduced by the authors to meet a specific ICT and STEM study environment: the first version of the ICT \& STEM SQ-SS-WoM scale was proposed as a sixty-item structured questionnaire using a fivepoint Likert type scale, ranging from 1 = strongly disagree to 5 = strongly agree (Meštrović, 2017). The greater score indicated a higher level of SQ, SS, and positive WoM intentions. The 
Dunja Meštrović, Nina J.Zugic

TABLE 1: Rotated component matrix

\begin{tabular}{|c|c|c|c|c|c|c|c|}
\hline \multirow{2}{*}{ Item } & \multicolumn{7}{|c|}{ Component } \\
\hline & 1 & 2 & 3 & 4 & 5 & 6 & 7 \\
\hline AS2 & 0.852 & 0.130 & -0.189 & 0.569 & 0.444 & -0.055 & 0.093 \\
\hline AS4 & 0.671 & 0.145 & -0.011 & 0.129 & 0.100 & -0.070 & 0.089 \\
\hline AS5 & 0.715 & 0.169 & 0.248 & 0.162 & 0.064 & 0.131 & 0.023 \\
\hline EE1 & 0.096 & 0.754 & 0.216 & -0.017 & 0.015 & 0.642 & 0.002 \\
\hline EE14 & 0.136 & 0.726 & 0.141 & 0.084 & 0.143 & 0.616 & 0.237 \\
\hline EE19 & 0.069 & 0.728 & 0.114 & 0.397 & 0.354 & 0.004 & 0.191 \\
\hline EE3 & 0.314 & 0.770 & 0.176 & 0.050 & 0.027 & 0.390 & 0.114 \\
\hline 11 & 0.252 & 0.212 & 0.797 & 0.111 & 0.089 & -0.051 & 0.166 \\
\hline 12 & 0.137 & 0.394 & 0.789 & 0.131 & 0.211 & 0.137 & 0.305 \\
\hline 16 & 0.214 & 0.006 & 0.746 & -0.041 & 0.253 & 0.173 & 0.278 \\
\hline 17 & 0.280 & 0.183 & 0.852 & 0.047 & 0.236 & -0.036 & 0.299 \\
\hline 18 & 0.486 & 0.141 & 0.899 & 0.092 & 0.443 & -0.127 & 0.448 \\
\hline 19 & 0.478 & 0.123 & 0.799 & 0.049 & 0.485 & -0.160 & 0.443 \\
\hline SPTS4 & 0.359 & 0.183 & 0.121 & 0.796 & 0.279 & 0.375 & 0.265 \\
\hline SPTS7 & 0.289 & 0.140 & -0.006 & 0.739 & 0.207 & 0.701 & -0.084 \\
\hline SPTS8 & 0.204 & 0.092 & 0.213 & 0.764 & 0.082 & 0.754 & 0.181 \\
\hline SPTS9 & 0.230 & 0.040 & 0.194 & 0.853 & 0.116 & 0.790 & 0.140 \\
\hline TS1 & 0.285 & 0.160 & 0.004 & 0.387 & 0.815 & -0.041 & -0.106 \\
\hline TS2 & 0.299 & 0.179 & -0.010 & 0.370 & 0.849 & -0.036 & -0.028 \\
\hline TS3 & 0.200 & 0.241 & 0.035 & 0.169 & 0.824 & -0.037 & 0.077 \\
\hline TS4 & 0.353 & 0.026 & 0.160 & 0.073 & 0.836 & 0.157 & 0.166 \\
\hline TS5 & 0.294 & -0.036 & 0.133 & 0.021 & 0.768 & 0.109 & 0.118 \\
\hline TS6 & 0.200 & 0.017 & 0.130 & 0.297 & 0.761 & 0.120 & 0.286 \\
\hline TS8 & 0.243 & 0.110 & 0.138 & -0.012 & 0.741 & 0.194 & 0.203 \\
\hline SS1 & 0.181 & 0.190 & 0.013 & -0.084 & 0.235 & 0.918 & 0.083 \\
\hline SS2 & 0.302 & 0.116 & 0.179 & 0.761 & -0.035 & 0.871 & 0.148 \\
\hline SS3 & 0.254 & 0.232 & 0.055 & 0.666 & 0.117 & 0.931 & 0.092 \\
\hline SS4 & 0.196 & 0.224 & 0.107 & 0.519 & 0.244 & 0.924 & 0.095 \\
\hline W1 & 0.265 & 0.147 & 0.144 & 0.130 & 0.254 & 0.291 & 0.902 \\
\hline W2 & 0.286 & 0.306 & 0.243 & -0.123 & 0.245 & 0.288 & 0.851 \\
\hline W3 & 0.212 & 0.085 & 0.066 & -0.053 & 0.211 & 0.197 & 0.845 \\
\hline
\end{tabular}

Source: Authors' calculation

ICT \& STEM SQ-SS-WoM scale included the fol-

lowing subscales: 53 items related to perceived SQ dimensions adapted from Legčević (2014), Dužević, Čeh Časni and Lazibat (2015) and proposed by the authors, 4 items related to SS at an institutional level that were adopted from Seng and Ling (2013), and 3 items related to positive WoM intentions that were adopted from Babin, Lee, Kim and Griffin (2005).
As suggested by Hill (1998), a convenient sample of 20 students enrolled in the final year of each ICT and STEM study program at the University of Rijeka (UniRi) were recruited for the pilot testing. Peterson's and Merunka's (2014) suggestion to gain insight about the adequacy of study resources; to identify variables of interest and decide how to operationalize each one in order to eliminate confusing or misleading 
questions; and to evaluate the logical consistency of categories, was employed for the scale development.

After validating the respondents' recommendations and responses accessed by the pilot questionnaire and psychometric evaluation (i.e. item analysis, internal consistency, and scale reliability), an exploratory factor analysis (EFA) using principal components analysis (PCA) with Varimax rotation was conducted to reduce the number of items and test the underlying dimensions of the construct. A Kaiser-Meyer-Olkin (KMO) measure of sampling adequacy, Bartlett's test of sphericity, and Cronbach's alphas for all dimensions were of acceptable values (i.e. higher than 0.7). A cut-odd point of 0.40 was determined for component loading and a minimum eigenvalue of 1.0 was set for retaining dimensions; thus, 29 dimensions found to be unsatisfactory concerning the perceptions of SQ were excluded.

As a result, the final set of 31 items shown in Table 2 - consisting of 24 items related to perceived SQ dimensions, 4 items related to SS at an institutional level, and 3 items related to positive WoM intentions - was retained for subsequent data collection for the next and final step of the ICT \& STEM SQ-SS-WOM scale development process.

TABLE 2: ICT \& STEM SQ-SS-WoM scale dimensions and items

\begin{tabular}{|c|c|c|}
\hline Dimensions and items & Code & Source \\
\hline \multicolumn{3}{|l|}{ Service Quality } \\
\hline \multicolumn{3}{|l|}{ a) Teaching staff } \\
\hline $\begin{array}{l}\text { 1. Academic staff is caring and courteous towards } \\
\text { students. }\end{array}$ & TS1 & Dužević et al. (2015) \\
\hline 2. Academic staff has a positive attitude towards students. & TS2 & Dužević et al. (2015) \\
\hline $\begin{array}{l}\text { 3. Academic staff shows sincere interest in solving } \\
\text { students' problems. }\end{array}$ & TS3 & Dužević et al. (2015) \\
\hline 4. Academic staff has good communication skills. & TS4 & Dužević et al. (2015) \\
\hline 5. Academic staff is knowledgeable in course content. & TS5 & Dužević et al. (2015) \\
\hline $\begin{array}{l}\text { 6. Academic staff provides efficient and courteous } \\
\text { consultations. }\end{array}$ & TS6 & Dužević et al. (2015) \\
\hline $\begin{array}{l}\text { 7. Academic staff is highly educated and experienced and } \\
\text { possesses knowledge and experience related to their } \\
\text { courses. }\end{array}$ & TS8 & Dužević et al. (2015) \\
\hline \multicolumn{3}{|l|}{ b) Administrative staff } \\
\hline $\begin{array}{l}\text { 8. Students' Service Office staff is efficient/prompt in } \\
\text { dealing with students' complaints. }\end{array}$ & AS2 & $\begin{array}{l}\text { Adapted from Dužević et } \\
\text { al. (2015) }\end{array}$ \\
\hline $\begin{array}{l}\text { 9. Department's administrative staff is efficient/prompt in } \\
\text { dealing with students' complaints. }\end{array}$ & AS4 & $\begin{array}{l}\text { Adapted from Dužević et } \\
\text { al. (2015) }\end{array}$ \\
\hline $\begin{array}{l}\text { 10. Department's administrative staff is available and ready } \\
\text { to provide students with assistance. }\end{array}$ & AS5 & $\begin{array}{l}\text { Adapted from Legčević } \\
(2014)\end{array}$ \\
\hline \multicolumn{3}{|l|}{ c) Study programs and teaching syllabus } \\
\hline $\begin{array}{l}\text { 11. This HEI has a system that increases the competitiveness } \\
\text { and employability of students. }\end{array}$ & SPTS4 & Authors \\
\hline 12. I am satisfied with the HEl's range and offer of e-courses. & SPTS7 & $\begin{array}{l}\text { Adapted from Dužević et } \\
\text { al. (2015) }\end{array}$ \\
\hline $\begin{array}{l}\text { 13. I am satisfied with the HEl's range and offer of elective } \\
\text { courses. }\end{array}$ & SPTS8 & $\begin{array}{l}\text { Adapted from Dužević et } \\
\text { al. (2015) }\end{array}$ \\
\hline
\end{tabular}




\begin{tabular}{|c|c|c|}
\hline Dimensions and items & Code & Source \\
\hline $\begin{array}{l}\text { 14. I am satisfied with the HEl's range and offer of joint } \\
\text { elective courses. }\end{array}$ & SPTS9 & $\begin{array}{l}\text { Adapted from Dužević et } \\
\text { al. (2015) }\end{array}$ \\
\hline \multicolumn{3}{|l|}{ d) Environment and equipment } \\
\hline 15. The HEl has an ideal campus location/layout. & EE1 & Dužević et al. (2015) \\
\hline $\begin{array}{l}\text { 16. Academic facilities have adequate equipment for classes, } \\
\text { exercises, and seminars. }\end{array}$ & EE3 & Dužević et al. (2015) \\
\hline $\begin{array}{l}\text { 17. I am satisfied with the Rijeka Student Centre's food } \\
\text { and accommodation services, and mediation in } \\
\text { contemporary and periodical employment. }\end{array}$ & EE14 & Authors \\
\hline $\begin{array}{l}\text { 18. Dormitory buildings are visually appealing and offer } \\
\text { adequate accommodation facilities. }\end{array}$ & EE19 & $\begin{array}{l}\text { Adapted from Dužević et } \\
\text { al. (2015) }\end{array}$ \\
\hline \multicolumn{3}{|l|}{ e) Image } \\
\hline $\begin{array}{l}\text { 19. The HEl values and recognizes students' feedback for } \\
\text { improvement. }\end{array}$ & 11 & Dužević et al. (2015) \\
\hline $\begin{array}{l}\text { 20. The HEI has standardized and simple service delivery } \\
\text { procedures (e.g. informing students, including students } \\
\text { in the work of the HEl, counselling etc.). }\end{array}$ & 12 & Dužević et al. (2015) \\
\hline 21. The HEl's staff is easily contacted (e-mail, telephone). & 16 & Dužević et al. (2015) \\
\hline $\begin{array}{l}\text { 22. The HEl provides services within a reasonable time } \\
\text { frame. }\end{array}$ & 17 & Dužević et al. (2015) \\
\hline 23. The HEl displays a professional image. & 18 & Dužević et al. (2015) \\
\hline 24. The HEl provides reputable academic programs. & 19 & Dužević et al. (2015) \\
\hline \multicolumn{3}{|l|}{ Students' satisfaction } \\
\hline 25. Study experience has met my expectations. & SS1 & $\begin{array}{l}\text { Adapted from Seng \& Ling } \\
(2013)\end{array}$ \\
\hline 26. This HEl is just how I would like it to be. & SS2 & $\begin{array}{l}\text { Adapted from Seng \& Ling } \\
(2013)\end{array}$ \\
\hline 27. I am satisfied with this HEl. & SS3 & $\begin{array}{l}\text { Adapted from Seng \& Ling } \\
\text { (2013) }\end{array}$ \\
\hline $\begin{array}{l}\text { 28. Thinking back on your experience within the HEl, how } \\
\text { do you rate your overall satisfaction? }\end{array}$ & SS4 & $\begin{array}{l}\text { Adapted from Seng \& Ling } \\
(2013)\end{array}$ \\
\hline \multicolumn{3}{|l|}{ WoM intention } \\
\hline $\begin{array}{l}\text { 29. I will recommend this HEl to my friends, relatives, and/or } \\
\text { acquaintances. }\end{array}$ & W1 & $\begin{array}{l}\text { Adapted from Babin et al. } \\
(2005)\end{array}$ \\
\hline $\begin{array}{l}\text { 30. I will say positive things about the aspects of my study } \\
\text { experience and this } \mathrm{HEl} \text { to my friends, relatives, and/or } \\
\text { acquaintances. }\end{array}$ & W2 & $\begin{array}{l}\text { Adapted from Babin et al. } \\
(2005)\end{array}$ \\
\hline $\begin{array}{l}\text { 31. Given the opportunity to do it over again, I would } \\
\text { reconsider my decision to choose and enrol in this study } \\
\text { program. }\end{array}$ & W3 & $\begin{array}{l}\text { Adapted from Babin et al. } \\
\text { (2005) }\end{array}$ \\
\hline
\end{tabular}

Source: Authors

Consequently, the main 31-item survey was undertaken to examine the structure of the pro- posed measurement model, and the results obtained are discussed below. 


\subsection{Population, sampling, and data collection}

Relevant quantitative data was collected by means of an online anonymous self-administered structured questionnaire, used as part of a larger study aimed at exploring the following factors: perceived SQ, SS, study program efficiency, positive WoM intentions, reasons for choosing a particular study program, and information sources used during the decision-making process (Meštrović, 2017). Using Google Docs Forms, the questionnaire was distributed by e-mail to undergraduate and graduate students enrolled at UniRi in the ICT and three STEM academic programs, namely, biotechnology, mathematics, and physics.

The survey was conducted over a period of two months, during the middle of the summer semester of the academic year 2014/2015. Out of a total number of 873 students (32.52\% male and $67.48 \%$ female) then enrolled and surveyed in this study, 214 usable questionnaires (24.51\%) were returned for data analysis. Since Parasuraman and others (1988) and Marković (2006) used a sample size of 200 to analyze their data, a convenience sample of 214 was found to be suitable for this research; it also met sample size requirements for structural equation modelling (Wolf, Harrington, Clark \& Miller, 2013).

\subsection{Data analysis}

For the data analysis conducted in two stages, Statistica 12.7 and SmartPLS 3.0 software were used. The reliability of the proposed measurement instrument was confirmed using Cronbach's alpha, and simple descriptive statistical analysis was applied to examine the respondents' demographics.

\section{RESULTS}

\subsection{Respondents' characteristics}

The study examined the demographic variables of gender, age, study program level, study program area, tuition fee, and students' success achieved during studies. Out of the total of 214 respondents in this study, 140 (65.42\%) were female and 74 (34.58\%) were male. The calculated mean age of respondents was 22, with $48.60 \%$ of them being between 21 and 23 years old. Of the total number of respondents, 95 were ICT students (44.39\%) and 119 (55.61\%) were students enrolled in STEM study programs; 142 respondents (66.36 \%) were enrolled in undergraduate study programs, while 72 (33.64 \%) were enrolled in graduate study programs. All of them were full-time students, and $85.98 \%$ paid no tuition fees because they had been awarded grants by the Ministry of Science and Education (MSE) of the Republic of Croatia due to their academic success (Meštrović, 2017).

\subsection{Descriptive statistics}

According to the descriptive statistics shown in Table 2, both overall SS (subscale mean $=3.33$ ) and students' intention to spread positive WoM (subscale mean $=3.55$ ) were high. The mean scores for all subscales related to five SQ dimensions were above 3 (Meštrović, 2017), except for the subscale considering study programs and teaching syllabus, which resulted in a lower mean score of 2.92 . 
Dunja Meštrović, Nina J. Zugic

\section{TABLE 3: Descriptive statistics}

\begin{tabular}{|c|c|c|c|c|}
\hline Dimensions and items & Mean & Std. Dev. & Skewness & Kurtosis \\
\hline \multicolumn{5}{|l|}{ SQ $($ mean $=3.68)$} \\
\hline \multicolumn{5}{|c|}{ Teaching staff $($ mean $=3.80)$} \\
\hline TS1 & 3.75 & 1.151 & -0.909 & 0.023 \\
\hline TS2 & 3.60 & 1.133 & -0.698 & -0.322 \\
\hline TS3 & 3.55 & 1.124 & -0.298 & -0.892 \\
\hline TS4 & 3.70 & 1.027 & -0.631 & 0.063 \\
\hline TS5 & 3.97 & 0.911 & -1.139 & 1.726 \\
\hline TS6 & 4.13 & 0.899 & -0.847 & 0.132 \\
\hline TS8 & 3.96 & 0.959 & -0.958 & 0.800 \\
\hline \multicolumn{5}{|c|}{ Administrative staff $($ mean $=3.72)$} \\
\hline AS2 & 3.70 & 1.209 & -0.814 & -0.211 \\
\hline AS4 & 3.65 & 1.172 & -0.559 & -0.461 \\
\hline AS5 & 3.81 & 1.185 & -0.853 & 0.099 \\
\hline \multicolumn{5}{|l|}{ Image (mean $=3.52)$} \\
\hline 11 & 3.15 & 1.226 & -0.360 & -0.719 \\
\hline 12 & 3.27 & 1.117 & -0.297 & -0.525 \\
\hline 16 & 3.99 & 0.932 & -0.815 & 0.396 \\
\hline 17 & 3.59 & 1.020 & -0.510 & 0.229 \\
\hline 18 & 3.69 & 1.006 & -0.801 & 0.437 \\
\hline 19 & 3.44 & 1.085 & -0.421 & -0.474 \\
\hline \multicolumn{5}{|c|}{ Environment and equipment (mean = 3.19) } \\
\hline EE1 & 3.39 & 1.262 & -0.392 & -0.819 \\
\hline EE14 & 3.07 & 1.271 & -0.146 & -1.078 \\
\hline EE19 & 2.71 & 1.122 & 0.189 & -0.266 \\
\hline EE3 & 3.60 & 1.190 & -0.582 & -0.540 \\
\hline \multicolumn{5}{|c|}{ Study programs and teaching syllabus (mean 2.92) } \\
\hline SPTS4 & 3.26 & 1.169 & -0.407 & -0.511 \\
\hline SPTS7 & 3.04 & 1.215 & -0.097 & -1.070 \\
\hline SPTS8 & 2.62 & 1.337 & -0.144 & -0.739 \\
\hline SPTS9 & 2.76 & 1.107 & 0.277 & -1.085 \\
\hline \multicolumn{5}{|l|}{ SS $($ mean $=3.33)$} \\
\hline SS1 & 3.34 & 1.234 & -0.720 & -0.655 \\
\hline SS2 & 2.99 & 1.175 & -0.087 & -0.901 \\
\hline SS3 & 3.47 & 1.306 & -0.595 & -0.794 \\
\hline SS4 & 3.52 & 0.972 & -0.424 & -0.294 \\
\hline \multicolumn{5}{|l|}{$\mathbf{W o M}($ mean = 3.55) } \\
\hline W1 & 3.55 & 1.247 & -0.687 & -0.475 \\
\hline W2 & 3.29 & 1.151 & -0.325 & -0.626 \\
\hline W3 & 3.82 & 1.410 & -0.777 & -0.637 \\
\hline
\end{tabular}

Source: Authors' calculation 


\subsection{Confirmatory factor analysis (CFA)}

To confirm the proposed measurement model shown in Figure 1 and suggested by the EFA, a concluding application of a confirmatory factor analysis (CFA), using a PCA extraction method with Varimax rotation, was conducted on 31 items to support the proposed structure model and to examine the ICT \& STEM SQ-SS-WoM scale's dimensionality.

Suitability for the factor analysis was determined by correlation and alpha reliability, variance percentage, factor importance explained with the correlation degree equalling or exceeding 0.50 (Nunnally, 1978), and factor structure. The analysis resulted in a high $\mathrm{KMO}$ value of 0.912 , indicating the data's suitability for factor analysis (Kaiser \& Rice, 1974). Bartlett's sphericity test indicated a chi-square value of 5204.994 with 465 degrees of freedom and a p-value of 0.000 $<0.05$, confirming that the variables were not unrelated and therefore were suitable for structure detection.

\section{TABLE 4: Confirmatory factor analysis}

\begin{tabular}{|c|c|c|c|c|c|c|}
\hline \multicolumn{2}{|c|}{ Constructs } & Items & $\begin{array}{l}\text { Standardized } \\
\text { loadings }\end{array}$ & CR & AVE & $\begin{array}{l}\text { Cronbach's } \\
\text { Alpha }\end{array}$ \\
\hline \multirow{24}{*}{$\begin{array}{l}\text { Service } \\
\text { Quality }\end{array}$} & \multirow{7}{*}{ Teaching staff } & TS1 & 0.859 & \multirow{7}{*}{0.957} & \multirow{7}{*}{0.619} & \multirow{7}{*}{0.906} \\
\hline & & TS2 & 0.858 & & & \\
\hline & & TS3 & 0.934 & & & \\
\hline & & TS4 & 0.890 & & & \\
\hline & & TS5 & 0.799 & & & \\
\hline & & TS6 & 0.709 & & & \\
\hline & & TS8 & 0.811 & & & \\
\hline & \multirow{3}{*}{ Administrative staff } & AS2 & 0.769 & \multirow{3}{*}{0.792} & \multirow{3}{*}{0.562} & \multirow{3}{*}{0.704} \\
\hline & & AS4 & 0.831 & & & \\
\hline & & AS5 & 0.926 & & & \\
\hline & \multirow{6}{*}{ Image } & 11 & 0.922 & \multirow{6}{*}{0.922} & \multirow{6}{*}{0.664} & \multirow{6}{*}{0.896} \\
\hline & & 12 & 0.757 & & & \\
\hline & & 16 & 0.874 & & & \\
\hline & & 17 & 0.866 & & & \\
\hline & & 18 & 0.877 & & & \\
\hline & & 19 & 0.903 & & & \\
\hline & \multirow{4}{*}{$\begin{array}{l}\text { Environment and } \\
\text { equippment }\end{array}$} & EE1 & 0.816 & \multirow{4}{*}{0.833} & \multirow{4}{*}{0.555} & \multirow{4}{*}{0.732} \\
\hline & & EE14 & 0.779 & & & \\
\hline & & EE19 & 0.834 & & & \\
\hline & & EE3 & 0.828 & & & \\
\hline & \multirow{4}{*}{$\begin{array}{l}\text { Study programs and } \\
\text { teaching syllabus }\end{array}$} & SPTS4 & 0.927 & \multirow{4}{*}{0.868} & \multirow{4}{*}{0.623} & \multirow{4}{*}{0.800} \\
\hline & & SPTS7 & 0.846 & & & \\
\hline & & SPTS8 & 0.755 & & & \\
\hline & & SPTS9 & 0.899 & & & \\
\hline \multirow{4}{*}{\multicolumn{2}{|c|}{ Students' satisfaction }} & SS1 & 0.984 & \multirow{4}{*}{0.951} & \multirow{4}{*}{0.830} & \multirow{4}{*}{0.928} \\
\hline & & SS2 & 0.998 & & & \\
\hline & & SS3 & 0.986 & & & \\
\hline & & SS4 & 0.790 & & & \\
\hline \multirow{3}{*}{\multicolumn{2}{|c|}{ Word of mouth }} & W1 & 0.906 & \multirow{3}{*}{0.901} & \multirow{3}{*}{0.752} & \multirow{3}{*}{0.831} \\
\hline & & W2 & 0.922 & & & \\
\hline & & W3 & 0.807 & & & \\
\hline
\end{tabular}


All items loaded significantly on the respective constructs, with loadings above the value of 0.60; no evidence of cross-loadings was found, and the $72.26 \%$ of variance explained the 31 attributes that were captured under underlying factors. The CFA provided evidence for convergent validity, confirming the extracted dimensions proposed by the EFA.

\subsection{Measurement scale analysis}

Partial least squares (PLS) structural equation modelling (SEM) was employed, using SmartPLS software to check the significance of each of the dimensions in the proposed model and to visually examine the relationships among the variables. The process of ICT \& STEM SQ-SS-WOM scale evaluation consisted of internal consistency (Cronbach's Alpha), composite reliability $(C R)$, convergent validity, and average variance extracted (AVE), according to the recommendations of Hair, Black, Babin and Anderson (2010).

The Cronbach's alpha value for the entire ICT \& STEM SQ-SS-WoM Scale was 0.952, demonstrating excellent reliability (DeVellis, 2003). All SQ subscales' Cronbach's alpha values were higher than 0.70 (Nunnally, 1978): the subscale with items concerning teaching staff (TS) achieved a Cronbach's alpha value of 0.06; the subscale with items concerning administrative staff (AS) achieved a Cronbach's alpha value of 0.704; the subscale with items concerning image (I) achieved a Cronbach's alpha value of 0.896; the subscale with items concerning environment and equipment (EE) achieved a Cronbach's al- pha value of 0.732; the subscale with items concerning study programs and teaching syllabus (SPTS) achieved a Cronbach's alpha value of 0.800. The subscale with items concerning SS achieved a Cronbach's alpha value of 0.928, and the subscale with items concerning positive WoM intentions achieved a Cronbach's alpha value of 0,831, as shown in Table 4. Accordingly, the internal consistency of the proposed measurement model was confirmed.

To indicate a proposed measurement scale as reliable, the $C R$ values should be greater than 0.60 and the AVE values should be greater than 0.50 (Hair et al., 2010). The proposed structural model's composite and convergent reliability analysis resulted in acceptable CR values, ranging between 0.901 and 0.956, and AVE values in the range from 0.502 to 0.830 . The proposed model's overall CR achieved the value of 0.984 , and the AVE for all items was $65.93 \%$, thus indicating acceptable composite and convergent validity, as shown in Table 5. However, the establishment of discriminant validity was not confirmed, as the AVE value of SQ achieved the marginally acceptable value of 0.502. Furthermore, the shared variance (i.e. squared correlation) of the SQ-SS relationship resulted in a value of 0.508 , and the shared variance of the SS-WoM relationship resulted in a value of 0.801 , both of which are higher than the value of SQ's AVE (0.502).

The retrieved model's absolute measure of fit, i.e. the standardized root mean square residual (SRMR) value of 0.051 (Henseler et al., 2014), the

TABLE 5: ICT \& STEM SQ-SS-WoM convergent and discriminant validity

\begin{tabular}{|l|c|c|c|c|c|c|}
\hline \multirow{2}{*}{ Constructs } & \multicolumn{3}{|c|}{ Correlations } & \multirow{2}{*}{ CR } & AVE & $\begin{array}{c}\text { Cronbach's } \\
\text { Alpha }\end{array}$ \\
\cline { 2 - 6 } & SQ & SS & WoM & & & 0.956 \\
\hline SQ & $\mathbf{0 . 7 0 9}$ & & & 0.502 & 0.956 \\
\hline SS & 0.896 & $\mathbf{0 . 9 1 1}$ & & 0.951 & 0.830 & 0.928 \\
\hline WoM & 0.769 & 0.859 & $\mathbf{0 . 8 6 7}$ & 0.901 & 0.752 & 0.831 \\
\hline
\end{tabular}

* Composite Reliability (CR); Average Variance Extracted (AVE); Square Root of the AVE (marked bold); Correlations between constructs (off-diagonal)

Source: Authors' calculation 
HTMT values lower than 0.90 (Gold, Malhotra \& Segars, 2001) and ranging between 0.656 and 0.895 , and the Cronbach's alpha values shown in Table 3 for each factor above the value of 0.70 confirmed the reliability of the measurement instrument at a confidence level of 0.05. The obtained fit indices indicated that the proposed and adapted ICT \& STEM SQ-SS-WoM measurement scale was acceptable.

\section{DISCUSSION}

The main objective of this empirical research was to design a multidimensional measurement tool to assess ICT and STEM students' perceptions of $\mathrm{HE} \mathrm{SQ}$, their overall satisfaction, and their intentions to spread positive WoM. Based on the results of relevant studies by Legčević (2014), Dužević and others (2015), Seng and Ling (2013), and Babin and others (2005), a 31-item ICT \& STEM SQ-SS-WoM scale was designed. Statistical tests applied at two different stages of the empirical research helped develop and improve the scale, confirming the validity and the reliability of the measurement tool.

After confirming the suitability of the measurement scale, the CFA yielded factor loadings of all the scale's items with a value higher than 0.60, thus confirming the proposed model and the derived dimensions of the EFA in the pilot study. The ICT \& STEM SQ-SS-WoM scale's psychometric evaluation showed excellent reliability (Cronbach's Alpha 0.952), resulting in CR values above the value of 0.90, and AVE values in the rangee from 0.502 to 0.830 , thus confirming the scale's validity and reliability. Since the discriminant validity was not established, conclusions regarding relationships in structural models should be used with caution.

\section{LIMITATIONS AND FUTURE RESEARCH}

The importance of ICT and STEM students' specific needs within the HE makes the development of a multidimensional measurement scale more urgent, as this important topic is relevant to the methodological grounds (Goyette, Ricard, Bergeron \& Marticotte, 2010). With its distinctive SQ dimensions, the ICT and STEM SQ-SS-WOM scale is an applicable measurement instrument in the Croatian ICT and STEM HE context.

Future research should be undertaken on a representative sample of a different target group of students and compared with these results, as the outcome of follow-up studies would be of particular significance to the HEl's management. In addition, future studies have been proposed to explore how critical SQ emerged factors are predicting SS and students' positive WoM intentions, using the appropriate methodology. The lack of discriminant validity accentuates the necessity of future research to further examine, improve, and ensure the rigor of empirical testing and validation of this theory.

The scope of this research is student-centered, hence its limitation. Being aware of the presence of other stakeholders in the HE context - i.e. university staff, employers, government, funding bodies, the labour market, and the society as a whole - due to the time and financial limitations, the scope of this research was confined only to the perspective of students. Widening the student-centered scope and accessing the perspectives of other stakeholders is the authors' recommendation for future research.

The results of this study are consistent and in agreement with similar studies (Legčević, 2014; Hasan, Ilias, Pahman \& Razak, 2009; Malik, Danish \& Usman, 2010; Bigne et al., 2003; Athiyaman, 1997). The SQ and SS in the HE context, coupled with the strategic importance of WoM as a communication medium for organizations, are widely presented in relevant scientific literature. Even more importantly, as they follow EU policy on ICT and STEM students within higher education, this research will contribute considerably to the importance of ICT and STEM HEls in Croatia. Since the reliability of the proposed measurement scale is high in the given sample, there is a strong possibility that other study areas, and other HEls as well, will use this newly

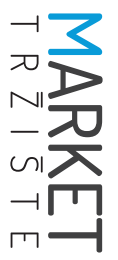


adapted and adopted tool to gain insight into students' perceptions of SQ, SS, and intentions to spread positive WoM. They may also used them to determine distinctive SQ dimensions that need improvement or those which need to remain at the same level in order to create a better learning environment that would satisfy ICT and STEM students' specific requirements. The fact that satisfied students are expected to spread positive WoM to their friends, relatives, and acquaintances plays an important role in prospective students' decision-making processes.

\section{CONCLUSION}

In order to design and propose a newly adapted, adopted, and validated measurement tool of the ICT and STEM students' perceptions of SQ, SS, as well as students' positive WoM intentions, this study used the concepts clearly defined in the extant literature.

Hence, the multidimensional ICT \& STEM SQ-SSWoM measurement scale, consisting of a total of 31 items, including 24 items that measure the five-factor construct of SQ, 4 items related to SS at an institutional level, and 3 items related to positive WoM intentions, was adapted and adopted for the study. The scale was developed within the context of HE services, with high levels of reliability, convergent validity, and content validity. The theoretical research conduct- ed in this study determined the existence of an awareness of considerable compulsion to investigate and consider SS for the HEl's positioning and effectiveness in a competing HE marketplace (Middaugh, 2010), among the increasing number of marketized HEls, all proactive in making marketing orientation with a long-term perspective an integral part of their system.

To the authors' best knowledge, such a measurement scale has not been developed within the context of ICT and STEM students in HE in Croatia. The findings and the outcomes of this research on the students' SQ, SS, and positive WoM intentions will be of crucial importance to the researchers themselves, as well as to practitioners and policy makers in Croatia and across the EU.

In conclusion, the proposed measurement instrument, adapted and adopted to the specifics of the ICT and STEM HE context in Croatia, encompassed a comprehensive concept of students' perceptions of $S Q$, their overall satisfaction with SS, and the spread of positive WoM. Thus, this empirical research is a valuable scientific contribution that introduces a newly adapted, adopted, validated, and successfully tested ICT \& STEM SQ-SS-WoM Scale. The present study fulfils the above-mentioned criteria, and most importantly, fills in a literature gap within the ICT and STEM HE SQ field of research.

\section{REFERENCES}

1. Ahmed, I., Nawaz, M. M., Ahmad, Z., Ahmad, Z., Shaukat, M. Z., Usman, A., Wasim-ul-Rehman, W., \& Ahmed, N. (2010). Does Service Quality Affect Students' Performance? Evidence from Institutes of Higher Learning. African Journal of Business Management, 4(12), 2527-2533.

2. Alves, H., \& Raposo, M. (2010). The Influence of University Image on Students' Behavior. International Journal of Educational Management, 24(1), 73-85.

3. Anderson, E. W. (1998). Customer satisfaction and word of mouth. Journal of Service Research, 1(1), 5-17.

4. Arslanagić-Kalajdžić, M., Kadić-Maglajlić, S., \& Čičić, M. (2014). Students' Perceptions about Role of Faculty and Administrative Staff in Business Education Service Quality Assessment. Market-Tržište, 26(1), 93-108.

5. Athiyaman, A. (1997). Linking student satisfaction and service quality perceptions: the case of university education. European Journal of Marketing, 31(7), 528-540. 
6. Babin, B. J., Lee, Y. K., Kim, E. J., \& Griffin, M. (2005). Modelling consumer satisfaction and word-ofmouth: restaurant patronage in Korea. Journal of Services Marketing, 19(3), 133-139.

7. Bansal, H. S., \& Voyer, P. A. (2000). Word-of-mouth processes within a service purchase decision context. Journal of Service Research, 3(2), 166-177.

8. Berry, L. L., Parasuraman, A., \& Zeithaml, V. A. (1988). The service - quality puzzle. Business Horizons, 31(5), 35-43.

9. Bigne, E., Moliner, M. A., \& Sanchez, J. (2003). Perceived quality and satisfaction in multi service organizations: The case of Spanish public services. The Journal of Services Marketing, 17(4), 420442.

10. Bristor, J. M. (1990). Enhanced Explanations of Word of Mouth Communications: The Power of Relationships. Research in Consumer Behavior, 4, 51-83.

11. Cristobal, E., Flavian, C., \& Guinaliu, M. (2007). Perceived e-service quality: measurement validation and effects on consumer satisfaction and web site loyalty. Managing Service Quality, 17(3), 317-340.

12. Cronin, J. J., Brady, M. K., \& Hult, G. T. M. (2000). Assessing the effects of quality, value and customer satisfaction on consumer behavioral intentions in service environments. Journal of Retailing, 76(2), 193-218.

13. Davidow, M., \& Leigh, J. H. (1998). The effects of organizational complaint responses on consumer satisfaction, word-of-mouth activity and repurchase intentions. Journal of Consumer Satisfaction, Dissatisfaction and Complaining Behavior, 11(1), 91-102.

14. DeShields Jr., O. W., Kara, A., \& Kaynak, E. (2005). Determinants of Business Student Satisfaction and Retention in Higher Education: Applying Herzberg's Two-Factor Theory. International Journal of Educational Management, 19(2), 128-139.

15. DeVellis, R. F. (2003). Scale Development: Theory and Applications. Thousand Oaks, CA: SAGE Publications.

16. Dužević, I., Čeh Časni, A., \& Lazibat, T. (2015). Students' Perception of the Higher Education Service Quality. Croatian Journal of Education: Hrvatski časopis za odgoj i obrazovanje, 17(4), 37-67.

17. Elliott, K. M, \& Shin, D. (2002). Student Satisfaction: An alternative approach to assessing this important concept. Journal of Higher Education Policy and Management, 24(2), 197-209.

18. Elliott, K. M., \& Healy, M. A. (2001). Key factors influencing student satisfaction related to recruitment and retention. Journal of marketing for higher education, 10(4), 1-11.

19. File, M. K., Cermak, D. S. P., \& Prince, R. A. (1994). Word-of-mouth effects in professional service buyer behaviour. The Service Industries Journal, 14(3), 301-314.

20. Fullerton, G., \& Taylor, S. (2002). Mediating, interactive, and non-linear effects in service quality and satisfaction with services research. Canadian Journal of Administrative Sciences, 19(2), 124-136.

21. Gallifa, J., \& Batalle, P. (2010). Student Perceptions of Service Quality in a Multi- Campus Higher Education System in Spain, Quality Assurance in Education, 18(2), 156-170.

22. Gerbing, D. W., \& Anderson, J. C. (1988). An updated paradigm for scale development incorporating unidimensionality and its assessment. Journal of Marketing Research, 25(2), 186-192.

23. Godes, D., \& Mayzlin, D. (2004). Using online conversations to study word-of-mouth communication. Marketing Science, 23(4), 545-560.

24. Gold, A. H., Malhotra, A., \& Segars, A. H. (2001). Knowledge management: an organizational capabilities perspective. Journal of Management Information Systems, 18(1), 185-214.

25. Goyette, I., Ricard, L., Bergeron, J., \& Marticotte, F. (2010). E-WOM Scale: Word-of-Mouth Measurement Scale for e-Services Context. Canadian Journal of Administrative Sciences, 27(1), 5-23.

26. Hair, J., Black, W., Babin, B., \& Anderson, R. (2010). Multivariate Data Analysis. Upper Saddle River, NJ: Prentice-Hall. 
27. Harrison-Walker, L. J. (2001). The measurement of word-of-mouth communication and an investigation of service quality and customer commitment as potential antecedents. Journal of Service Research, 4(1), 60-75.

28. Hasan, H. F. A., llias, A., Rahman, R. A., \& Razak, M. Z. A. (2009). Service quality and student satisfaction: a case study at private higher education institutions. International Business Research, 1(3), 163-175.

29. Henseler, J., Dijkstra, T. K., Sarstedt, M., Ringle, C. M., Diamantopoulos, A., Straub, D. W., Ketchen, D. J. Jr., Hair, J. F., Hult, G. T. M., \& Calantone, R. J. (2014). Common beliefs and reality about PLS: comments on Rönkkö \& Evermann (2013). Organizational Research Methods, 17(2), 182-209.

30. Hill, R. (1998). What sample size is "enough" in internet survey research?. Interpersonal Computing and Technology: An Electronic Journal for the 215t Century, 6(3/4), 1-12.

31. Imrie, B. C., Durden, G., \& Cadogan, J. W. (2000). Towards a conceptualization of service quality in the global market arena. Advances in International Marketing, 10(1), 143-162.

32. Johns, N., Avci, T., \& Karatepe, O. (2004). Measuring service quality of travel agents: evidence from Northern Cyprus. The Service Industries Journal, 24(3), 82-100.

33. Joyce, A. (2014). Stimulating interest in STEM careers among students in Europe: Supporting career choice and giving a more realistic view of STEM at work. $3^{\text {rd }}$ Education and Employers Taskforce Research Conference: Exploring School-to-Work Transitions in International Perspectives. London. Availabele at: http://www.educationand employers.org/wpcontent/uploads/2014/06/ joyce_stimulating_interest_in_stem_careers_among_students_in_europe.pdf

34. Kaiser, H. F., \& Rice, J. (1974). Little Jiffy, Mark IV. Educational and Psychological Measurement, 34(1), 111-117.

35. Kotler, P., \& Clarke, R. N. (1987). Marketing For Health Care Organizations. Englewood Cliffs, NJ: Prentice-Hall.

36. Legčević, J. (2014). Linking higher education and economy as a role for regional development. In: A. Mašek-Tonković (ed.), Economy of Eastern Croatia - Vision and Growth (pp. 185-194). Osijek: Faculty of Economics in Osijek.

37. Lewis, B. R. (1989). Quality in service sector - a review. International Journal of Brand Marketing, 7(1), 4-12.

38. Malik, M. E., Danish, R. Q., \& Usman, A. (2010). The impact of service quality on students' satisfaction in higher education Institutes of Punjab. Journal of Management Research, 2(2), 1-11.

39. Marković, S. (2006). Students' Expectations and Perceptions in Croatian Tourism and Hospitality Higher Education: SERVQUAL versus UNIQUAL. South East European Journal of Economics \& Business, 1(2), 78-96.

40. Mazzarol, T., \& Soutar, G. N. (2002). Push-pull factors influencing international student destination choice. International Journal of Educational Management, 16(2), 82-90.

41. Meštrović, D. (2017). Service Quality, Students' Satisfaction and Behavioural Intentions in STEM and IC Higher Education Institutions. Interdisciplinary Description of Complex Systems: INDECS, 15(1), 66-77.

42. Middaugh, M. F. (2010). Planning and assessment in higher education: Demonstrating Institutional Effectiveness. San Francisco, CA: Jossey-Bass.

43. Murray, K. B. (1991). A test of services marketing theory: consumer information acquisition activities. Journal of Marketing, 55(1), 10-25.

44. Murray, K. B., \& Schlacter, J. L. (1990). The impact of services versus goods on consumers. Journal of the Academy of Marketing Science, 18(1), 51-65.

45. Nunnally, J. C. (1978). Psychometric Theory ( $2^{\text {nd }}$ ed.). New York, NY: McGraw-Hill.

46. Oliver, R. L. (1981). Measurement and Evaluation of satisfaction processes in retail settings. Journal of Retailing, 57(3), 25-48. 
47. Parasuraman, A., Zeithaml, V. A., \& Berry, L. L. (1988). SERVQUAL: A Multiple-Item Scale for Measuring Consumer Perceptions of Service Quality. Journal of Retailing, 64(1), 12-40.

48. Peterson, R. A., \& Merunka, D. R. (2014). Convenience samples of college students and research reproducibility. Journal of Business Research, 67(5), 1035-1041.

49. Reichheld, F. F. (2003). The one number you need to grow. Harvard business review, 81(12), 46-55.

50. Reichheld, F., \& Dado Jr., W. E. (1990). Zero defections: quality comes to services. Harvard Business Review, 68(5), 105-111.

51. Richardson, J. T. E. (2005). Instruments for obtaining student feedback: A review of the literature. Assessment and Evaluation in Higher Education, 30(4), 387-415.

52. Sapri, M., Kaka, A., \& Finch, E. (2009). Factors That Influence Student's Level of Satisfaction With Regards To Higher Educational Facilities Services. Malaysian Journal of Real Estate, 4(1), 34-51.

53. Segoro, W. (2013). The influence of perceived service quality, mooring factor, and relationship quality on customer satisfaction and loyalty. Procedia-Social and Behavioral Sciences, 81, 306-310.

54. Seng, E. L. K., \& Ling, T. P. (2013). A Statistical Analysis of Education Service Quality Dimensions on Business School Students' Satisfaction. International Education Studies, 6(8), 136-146.

55. Udo, G. J., Bagchi, K. K., \& Kirs, P. J. (2011). Using SERVQUAL to assess the quality of e-learning experience. Computers in Human Behavior, 27, 1272-1283.

56. Vázquez, J. L., Aza, C. L., \& Lanero, A. (2015). Students' experiences of university social responsibility and perceptions of satisfaction and quality of service. Ekonomski Vjesnik/Econviews: Review of contemporary business, entrepreneurship and economic issues, 28(2), 25-39.

57. Webb, D., \& Jagun, A. (1997). Customer care, customer satisfaction, value, loyalty and complaining behavior: validation in a UK university setting. Journal of Consumer Satisfaction, Dissatisfaction and Complaining Behavior, 1, 139-151.

58. Wirtz, J., \& Chew, P. (2002). The effects of incentives, deal proneness, satisfaction and tie strength on word-of-mouth behaviour. International Journal of Service Industry Management, 13(2), 141162.

59. Wolf, E. J., Harrington, K. M., Clark, S. L., \& Miller, M. W. (2013). Sample Size Requirements for Structural Equation Models: An Evaluation of Power, Bias, and Solution Propriety. Educational and Psychological Measurement, 76(6), 913-934. 